\title{
HUBUNGAN PENDIDIKAN DAN PARITAS DENGAN KEJADIAN KEHAMILAN TIDAK DIINGINKAN PADA AKSEPTOR KB DI PKBI AS SAKINAH KABUPATEN PEMALANG TAHUN 2014
}

\author{
Kiki Ayu Apriliana ${ }^{1}$ Maftuchah ${ }^{2}$ Rose Nurhudhariani ${ }^{3}$ \\ 1,3Prodi D IV Kebidanan, STIKES Karya Husada Semarang \\ ${ }^{2}$ Prodi D III Kebidanan, STIKES Karya Husada Semarang \\ Email: maftuchah89@gmail.com
}

\begin{abstract}
Abstrak
Latar belakang : Tingginya angka aborsi akibat kehamilan tidak diinginkan adalah sebuah fakta yang tidak dapat dilihat hanya dari salah satu faktor saja. Kadang seseorang merasa jumlah anak yang dimiliki sudah cukup, tetapi ternyata hamil lagi. Dengan kata lain kehamilan itu tidak dikehendaki. Tingginya angka kematian ibu ini disebabkan oleh berbagai penyebab yang kompleks yaitu sosial, budaya, ekonomi, paritas, tingkat pendidikan, fasilitas pelayanan kesehatan, dan gender. Pasien yang datang ke klinik dengan akseptor KB pada tahun 2014 karena kehamilan yang tidak diinginkan yaitu sebanyak 108 pasien dari jumlah total 136 pasien yaitu sebanyak 38 pasien dengan tindakan Aspirasi Vakum Manual (AVM) dan sisanya melanjutkan kehamilannya yaitu 70 pasien. Tujuan Penelitian : Mengetahui hubungan pendidikan dan paritas dengan kejadian kehamilan tidak diinginkan pada akseptor KB di klinik As Sakinah Pemalang. Metode Penelitian : survei analitik dengan pendekatan retrospektif, menggunakan instrument rekam medik yang ada di klinik PKBI As Sakinah Pemalang Tahun 2014. Populasi dalam penelitian ini adalah semua ibu hamil dengan riwayat KB yang datang ke klinik PKBI As Sakinah Pemalang pada tahun 2014 sebanyak 108 orang. Hasil Penelitian : Ada hubungan antara pendidikan dengan kejadian kehamilan tidak diinginkan pada akseptor keluarga berencana di klinik PKBI As Sakinah Pemalang (p value $0,008<0,05)$. Ada hubungan antar paritas dengan kejadian kehamilan tidak diinginkan pada akseptor keluarga berencana di klinik PKBI As Sakinah Pemalang ( $\mathrm{p}$ value $0,009<0,05$ ). Saran : Memberikan informasi yang berguna untuk peningkatan pelayanan kesehatan yang bermutu dalam rangka mensukseskan gerakan keluarga berencana.
\end{abstract}

Kata kunci : Pendidikan, Paritas; Kehamilan Tidak Diinginkan

\section{THE CORRELATION BETWEEN EDUCATION AND PARITY WITH THE UNWANTED PREGNANCY AT KB ACCEPTOR IN CLINIC PKBI AS SAKINAH PEMALANG DISTRICT 2014 YEAR}

\begin{abstract}
Background : The height of number abortion of effect pregnancy not wanted was a fact which cannot be seen only from one of just just factor. Sometime somebody felt the child amount owned have enough, but pregnant in the reality again. Equally that pregnancy was not desired. This mother Mortality height because of various complex cause that were social, cultural, economic, parity, mount the education, facility of health service, and gender. Incoming patient to clinic with the acceptor KB in the year 2014 because undesirable pregnancy that were 108 patient from full scale 136 patient that were 38 patient with the Vacuum Aspiration Manual action ( AVM) And the rest continue its pregnancy that were 70 patient. Objective : To identify the correlation between education and parity with the unwanted pregnancy at KB acceptor in clinic PKBI As Sakinah Pemalang. Methods : In this research the writer used the analytic desain survey research with the approach of retrospectiv study. Research instrument used the note record of exist in clinic of PKBI As Sakinah Pemalang Year 2014, secunder date. Population in this research were all pregnant mothers with the incoming history KB to clinic of PKBI As Sakinah Pemalang in the year 2014 they were 108 people. Results : There was a significant correlation between the education with unwanted pregnancy at KB acceptor in clinic of PKBI As Sakinah Pemalang. Chi Square value of 11,792 and with a $p$ value of $0,008<0,05$ so Ho refused. There was a significant correlation between the parity with unwanted pregnancy at KB acceptor in clinic of PKBI As Sakinah Pemalang. Chi Square value of 9,439 and with a $\mathrm{p}$ value of $0,009<0,05$ so Ho refused. Suggestion : Giving information which was good for make-up of certifiable health service in order to success of family planning (KB) movement.
\end{abstract}

Keywords : Education; Parity; Unwanted Pregnancy 


\section{Pendahuluan}

Angka Kematian Ibu (AKI) di Indonesia masih tinggi, target AKI di Indonesia pada tahun 2015 adalah 102 kematian per 100.000 kelahiran hidup. Sementara itu AKI berdasarkan Survei Demografi dan Kesehatan Indonesia (SDKI) tahun 2007 sebesar 228 per 100.000 kelahiran hidup mengalami kenaikan yang cukup drastis menjadi 359 per 100.000 kelahiran hidup pada tahun 2013. Angka ini masih cukup jauh dari target yang harus dicapai pada tahun 2015 (Kadir Ruslan, 2014).

Meningkatnya AKI di Indonesia di sebabkan oleh tekanan dari aspek kependudukan. Hasil dari sensus penduduk 2010 menunjukkan meningkatnya pertumbuhan penduduk yang mencapai 1,49\% lebih tinggi dibanding periode 2000 yang hanya mencapai 1,45 persen. Tingginya laju pertumbuhan penduduk didorong tingginya angka kelahiran. Jumlah penduduk Indonesia pada 2010 mencapai 237,56 juta orang yang terdiri dari 119,51 juta orang laki-laki dan 118,05 juta orang perempuan (Prakarsa, 2013).

Salah satu upaya pemerintah dalam mengendalikan laju pertumbuhan penduduk yaitu dengan cara memberikan prioritas kepada keluarga melalui program BKKBN (Badan Kependudukan dan Keluarga Berencana Nasional) bekerja sama dengan Kementrian Kesehatan dengan menekan penyebab AKI yang terangkum menjadi 4 terlalu 3 terlambat yaitu terlalu tua usia, terlalu muda usia, terlalu banyak melahirkan,dan terlalu sering jarak kehamilan, sedangkan 3 terlambat yaitu terlambat mengambil keputusan, terlambat membawa ke rumah sakit untuk mendeteksi kelainan atau penyakit, dan terlambat penanganan oleh pelayanan kesehatan (Anonim, 2011).

Seiring dengan kemajuan zaman kebutuhan untuk memiliki anak perlu dibatasi, jangan sampai anak terlantar, untuk menjadikan anak yang berguna bagi masyarakat, negara dan agama diperlukan pendidikan khusus. Kadang-kadang seseorang merasa jumlah anak yang dimiliki sudah cukup, tetapi ternyata hamil lagi. Dengan kata lain kehamilan itu tidak dikehendaki (Praptohardjo, 2007).

Kehamilan tidak diinginkan dapat terjadi karena dua alasan utama, yaitu pasangan tidak menggunakan kontrasepsi atau metode kontrasepsi yang digunakan gagal. Banyak alasan mengapa banyak orang tidak menggunakan kontrasepsi untuk mencegah kehamilan tidak diinginkan, termasuk kurangnya akses informasi dan pelayanan $\mathrm{KB}$, kepercayaan suatu agama, tidak cukupnya pengetahuan tentang risiko kehamilan akibat hubungan seksual yang tidak terlindungi, dan terbatasnya kemampuan pengambilan keputusan bagi para perempuan dengan melihat dari hubungan seksual dan kontrasepsi yang digunakan (Praptohardjo, 2007). 
Insiden aborsi pada kehamilan tidak diinginkan secara global adalah sekitar 20 juta per tahun. Lebih dari 90\% aborsi terjadi di negara-negara sedang berkembang. Menurut WHO, dua pertiga perempuan di dunia yang mengalami KTD berakhir dengan penghentian kehamilan disengaja, dan mayoritas aborsi terjadi di negara berkembang dan menyumbang 50 \% dari seluruh kematian ibu akibat komplikasi berupa infeksi dan perdarahan. Komplikasi lain yang terjadi berupa sepsis, perdarahan, trauma genital dan abdominal, perforasi uterus, dan keracunan bahan aborsi (Kompas, 2012).

Faktor-faktor yang mempengaruhi ibu untuk melakukan upaya yang mengarah pada perilaku aborsi karena kehamilan tidak diinginkan diantaranya sikap klien, pengetahuan tentang alat kontrasepsi, dukungan sosial, agama, paritas, umur, pendidikan, ekonomi, status pernikahan, promosi kesehatan, dan kebijakan negara (Praptohardjo, 2007).

Pasien KTD yang datang ke klinik Perkumpulan Keluarga Berencana Indonesia (PKBI) As-Sakinah Pemalang pada tahun 2013 terdapat 135 pasien dari berbagai daerah dari dalam dan luar kota baik yang sudah menikah maupun belum menikah dengan berbagai alasan mereka menginginkan pelayanan KTD yang terdiri dari pasangan yang sudah menikah dan menggunakan kontrasepsi yaitu sebanyak 106 pasien dengan tindakan Aspirasi Vakum Manual (AVM) atau kurretase 58 pasien dan sisanya melanjutkan kehamilannya yaitu 48 pasien. Jumlah ini meningkat dari tahun sebelumnya yang berjumlah 130 kasus pada tahun 2012, pasangan yang sudah menikah dan menggunakan kontrasepsi yaitu sebanyak 95 pasien dengan tindakan Aspirasi Vakum Manual (AVM) atau kurretase 50 pasien dan sisanya melanjutkan kehamilannya yaitu 45 pasien pada tahun 2013 (Data RM Klinik As-Sakinah Pemalang 2013).

Pasien yang datang ke klinik dengan akseptor KB pada tahun 2014 karena kehamilan yang tidak diinginkan yaitu sebanyak 108 pasien dari jumlah total 136 pasien yaitu sebanyak 38 pasien dengan tindakan Aspirasi Vakum Manual (AVM) dan sisanya melanjutkan kehamilannya yaitu 70 pasien. Pasien datang ke klinik untuk konsultasi dan ada yang mengalami perdarahan pervaginam akibat upaya pengguguran kandungan dengan meminum obat-obatan atau jamu sehingga perlu dilakukan tindakan kurretase karena masih adanya sisa hasil konsepsi (abortus inkomplet) (Data RM Klinik As Sakinah Pemalang, 2014).

Atas dasar tersebut penulis tertarik untuk melakukan penelitian dengan judul “ Hubungan Pendidikan dan Paritas dengan Kejadian Kehamilan Tidak Diinginkan pada Akseptor Keluarga Berencana di Klinik PKBI As Sakinah Kabupaten Pemalang Tahun 2014““. 


\section{Tinjauan Teoritis}

Kehamilan Tidak Diinginkan (KTD)

1. Pengertian Kehamilan Tidak Diinginkan

Istilah kehamilan tidak diinginkan merupakan kehamilan yang tidak menginginkan anak sama sekali atau unwanted pregnancy dan kehamilan yang diinginkan tetapi tidak pada saat itu atau mistimed pregnancy (kehamilan terjadi lebih cepat dari yang telah direncanakan), sedangkan kehamilan yang diinginkan adalah kehamilan yang terjadi pada waktu yang tepat.

\section{Alasan Kehamilan Tidak Diinginkan}

Terdapat banyak alasan bagi seorang perempuan tidak menginginkan kehadiran seorang anak pada saat tertentu dalam hidupnya. Menurut Kartono, ada beberapa alasan yang membuat kehamilan itu tidak diinginkan, yaitu (Kartono, 2007) :

a. Kehamilan yang terjadi akibat perkosaan

b. Kehamilan datang pada saat yang belum diharapkan

c. Bayi dalam kandungan ternyata menderita cacat majemuk yang berat

d. Kehamilan yang terjadi akibat hubungan seksual diluar nikah.

Data di Perkumpulan Keluarga Berencana Indonesia (PKBI) Pemalang banyak pasien yang datang untuk konsultasi kehamilannya yang di catat lengkap dalam rekam medis (RM) yaitu pada kasus unsafe abortion yang bertujuan untuk menelusuri alasan-alasan mengapa perempuan banyak yang melakukan aborsi tidak aman beserta akibatnya, diperoleh jawaban atas terjadinya kehamilan yang tidak diinginkan pada informan dewasa yang sudah menikah, yaitu (PKBI, 2010) :

a. Anak sudah banyak, suami jarang kerja, dan sering mabuk.

b. Klien masih dalam kontrak kerja.

c. Ketika Klien dalam masa subur, suami selalu tidak mau tahu dan tidak pernah mau pakai kondom.

d. Umur Klien sudah tua dan anak sudah cukup

e. Tidak boleh hamil anak keempat karena sudah tiga kali operasi Caesar

f. Suami tidak bersedia menerima kehamilan lagi walaupun anak baru satu

g. Jarak antara anak terlalu dekat

h. Suami baru PHK, dan sering sakit sedangkan gaji isteri kecil

i. Tidak sanggup menanggung anak tambahan 


\section{Metode Penelitian}

Jenis penelitian ini adalah penelitian kuantitatif dengan pendekatan Retrospective Study.Populasi dalam penelitian ini adalah semua ibu hamil dengan riwayat KB yang datang ke klinik PKBI As Sakinah Pemalang pada tahun 2014 sebanyak 108 orang. Metode pengambilan sampel yang digunakan adalah Total sampling. Instrumen penelitian menggunakan catatan rekam medik yang telah ada di klinik PKBI As Sakinah Pemalang Tahun 2014, karena data yang peneliti gunakan adalah data sekunder. Untuk memudahkan dalam pengambilan data, peneliti membuat instrumen yang mengacu pada rekam medik dalam lembar observasi. Penelitian ini dilaksanakan pada bulan Juni sampai dengan Oktober 2015 .

\section{Hasil Penelitian}

\section{Hubungan Pendidikan dengan Kejadian Kehamilan Tidak Diinginkan di Klinik PKBI As Sakinah Pemalang}

Tabel 1 Tabulasi Silang Pendidikan dengan Kehamilan tidak Diinginkan di Klinik As Sakinah Tahun 2014.

\begin{tabular}{|c|c|c|c|c|c|c|c|c|}
\hline \multirow{3}{*}{ Pendidikan } & \multicolumn{4}{|c|}{$\begin{array}{c}\text { Kehamilan Tidak } \\
\text { Diinginkan }\end{array}$} & \multirow{2}{*}{\multicolumn{2}{|c|}{ Total }} & \multirow{3}{*}{$\begin{array}{l}\text { Nilai } \chi^{2} \\
\text { hitung }\end{array}$} & \multirow{3}{*}{$\mathrm{p}$} \\
\hline & \multicolumn{2}{|c|}{$\begin{array}{l}\text { Unwanted } \\
\text { Pregnancy }\end{array}$} & \multicolumn{2}{|c|}{$\begin{array}{c}\text { Mistimed } \\
\text { Pregnancy }\end{array}$} & & & & \\
\hline & $\mathrm{f}$ & $\%$ & $\mathrm{f}$ & $\%$ & $f$ & $\%$ & & \\
\hline Tidak Sekolah & 3 & 21,4 & 11 & 78.6 & 14 & 100 & \multirow{4}{*}{11,792} & \multirow{4}{*}{0,008} \\
\hline Pendidikan Dasar & 9 & 27,3 & 24 & 72,7 & 33 & 100 & & \\
\hline Pendidikan Menengah & 22 & 53,7 & 19 & 46,3 & 41 & 100 & & \\
\hline Pendidikan Tinggi & 13 & 65 & 7 & 35 & 20 & 100 & & \\
\hline Total & 47 & 43,5 & 61 & 56,5 & 108 & 100 & & \\
\hline
\end{tabular}

Berdasarkan hasil penelitian menunjukan bahwa responden berdasarkan pendidikan disaat kejadian kehamilan tidak diinginkan pada Akseptor Keluarga Berencana di Klinik PKBI As Sakinah Pemalang Tahun 2014 dari 14 orang yang tidak sekolah sebanyak 3 orang $(21,4 \%)$ kehamilan ibu tidak diinginkan sama sekalisedangkan kehamilan tidak diinginkan yang terjadi karena alasan waktu yang tidak tepat atau kehamilan ibu diingikan tetapi tidak saat itu sebanyak 11 orang (78.6\%). Berdasarkan hasil penelitian dari 33 responden yang berpendidikan dasar disaat kejadian kehamilan tidak diinginkan pada Akseptor Keluarga Berencana di Klinik PKBI As Sakinah Pemalang sebanyak 9 orang $(27,3 \%)$ kehamilan ibu tidak 
diinginkan sama sekali dan kehamilan tidak diinginkan yang terjadi karena alasan waktu yang tidak tepat atau kehamilan ibu diingikan tetapi tidak saat itu sebanyak 24 orang $(72,7 \%)$. Berdasarkan hasil penelitian dari 41 responden yang berpendidikan menengah pada Akseptor Keluarga Berencana di Klinik PKBI As Sakinah Pemalang sebanyak 22 orang $(53,7 \%)$ kehamilan ibu tidak diinginkan sama sekali dan kehamilan tidak diinginkan yang terjadi karena alasan waktu yang tidak tepat atau kehamilan ibu diingikan tetapi tidak saat itu sebanyak 19 orang (46,3\%). Berdasarkan hasil penelitian dari 20 responden yang berpendidikan tinggi pada Akseptor Keluarga Berencana di Klinik PKBI As Sakinah Pemalang sebanyak 13 orang (65\%) kehamilan ibu tidak diinginkan sama sekali dan kehamilan tidak diinginkan yang terjadi karena alasan waktu yang tidak tepat atau kehamilan ibu diingikan tetapi tidak saat itu sebanyak 7 orang $(35 \%)$.

Uji statistik dengan Chi Square didapatkan nilai $\chi^{2}$ hitung 11,792 dengan df (41) $\mathrm{x}(2-1)=3$, diperoleh $\chi^{2}$ tabel 7,81. Karena $\chi^{2}$ hitung 11,792> $\chi^{2}$ tabel 7,81. dan nilai (p) $0,001<0,05$ maka Ho ditolak, dan Ha diterima artinya ada hubungan antar pendidikan dengan kejadian kehamilan tidak diinginkan pada akseptor keluarga berencana di klinik PKBI As Sakinah Pemalang.

\section{Hubungan Paritas dengan Kejadian Kehamilan Tidak Diinginkan di Klinik PKBI}

\section{As Sakinah Pemalang}

Tabel 2 Tabulasi Silang Paritas dengan Kehamilan tidak Diinginkan di Klinik As Sakinah Tahun 2014.

\begin{tabular}{|c|c|c|c|c|c|c|c|c|}
\hline \multirow{3}{*}{ Paritas } & \multicolumn{4}{|c|}{$\begin{array}{c}\text { Kehamilan Tidak } \\
\text { Diinginkan }\end{array}$} & \multirow{2}{*}{\multicolumn{2}{|c|}{ Total }} & \multirow{3}{*}{$\begin{array}{l}\text { Nilai } \chi^{2} \\
\text { hitung }\end{array}$} & \multirow{3}{*}{$\mathrm{p}$} \\
\hline & \multicolumn{2}{|c|}{$\begin{array}{l}\text { Unwanted } \\
\text { Pregnancy }\end{array}$} & \multicolumn{2}{|c|}{$\begin{array}{l}\text { Mistimed } \\
\text { Pregnancy }\end{array}$} & & & & \\
\hline & $\mathrm{F}$ & $\%$ & $\mathrm{f}$ & $\%$ & $\mathrm{f}$ & $\%$ & & \\
\hline Primipara & 6 & 50 & 6 & 50 & 12 & 100 & & \\
\hline Multipara & 31 & 36,9 & 53 & 63,1 & 84 & 100 & 9,439 & 0,009 \\
\hline Grandemultipara & 10 & 83,3 & 2 & 16,7 & 12 & 100 & & \\
\hline Total & 47 & 43,5 & 61 & 56,5 & 108 & 100 & & \\
\hline
\end{tabular}

Berdasarkan hasil penelitian menunjukan bahwa responden berdasarkan paritas pada Akseptor Keluarga Berencana di Klinik PKBI As Sakinah Pemalang dari 12 orang yang jumlah anak tergolong primipara sebanyak 6 orang (50\%), pada kehamilan ibu tidak diinginkan sama sekali sedangkan kehamilan tidak diinginkan yang terjadi karena alasan waktu yang tidak tepat atau kehamilan ibu diingikan tetapi tidak saat itu 
sebanyak 6 orang (50\%). Berdasarkan hasil penelitian dari 84 responden yang jumlah anak tergolong multipara pada Akseptor Keluarga Berencana di Klinik PKBI As Sakinah Pemalang sebanyak 31 orang $(36,9 \%)$, pada kehamilan ibu tidak diinginkan sama sekali dan kehamilan tidak diinginkan yang terjadi karena alasan waktu yang tidak tepat atau kehamilan ibu diingikan tetapi tidak saat itu sebanyak 53 orang $(63,1 \%)$. Berdasarkan hasil penelitian dari 12 responden yang jumlah anak tergolong grandemultipara pada Akseptor Keluarga Berencana di Klinik PKBI As Sakinah Pemalang sebanyak 10 orang $(83,3 \%)$. Pada kehamilan ibu tidak diinginkan sama sekali dan kehamilan tidak diinginkan yang terjadi karena alasan waktu yang tidak tepat atau kehamilan ibu diingikan tetapi tidak saat itu sebanyak 2 orang $(16,7 \%)$.

Uji statistik dengan Chi Square didapatkan nilai $\chi^{2}$ hitung 9,439dengan df (3-1) $\mathrm{x}(2-1)=2$, diperoleh $\chi^{2}$ tabel 5,99. Karena $\chi^{2}$ hitung 9,439> $\chi^{2}$ tabel 5,99. dan nilai (p) 0,009 $<0,05$ maka Ho ditolak, dan Ha diterima artinya ada hubungan antar paritas dengan kejadian kehamilan tidak diinginkan pada akseptor keluarga berencana di klinik PKBI As Sakinah Pemalang.

\section{Pembahasan}

1. Hubungan Pendidikan dengan Kejadian Kehamilan tidak Diinginkan Pada Akseptor Keluarga Berencana di Klinik PKBI As Sakinah Pemalang

Hasil penelitian menunjukan bahwa ada hubungan pendidikan dengan kejadian kehamilan tidak diinginkan pada akseptor KB di Klinik PKBI As Sakinah di Kabupaten Pemalang dengan nilai p 0,008 $<\alpha=0,05$ yaitu dari 41 responden yang ada berpendidikan menengah terdapat responden yang kehamilan tidak diinginkan yang terjadi karena alasan waktu yang tidak tepat/kehamilan ibu diinginkan tetapi tidak pada saat itu sebanyak 19 orang (46,3\%). Karena seperti kebanyakan ibu-ibu yang datang ke Klinik PKBI As Sakinah Pemalang dengan kejadian kehamilan tidak diinginkan karena adanya alasan tertentu sehingga mereka mengalami kejadian KTD seperti kontrak pekerjaan yang tidak memperbolehkan hamil.

Dari hasil penelitian dari 41 responden yang berpendidikan menengah dengan kejadian kehamilan tidak diinginkan di Klinik PKBI As Sakinah Pemalang yang kehamilannya tidak diinginkan sama sekali sebanyak 22 orang $(53,7 \%)$. Karena ibu di Klinik PKBI As Sakinah Pemalang mengalami kegagalan melindungi diri dari kehamilan yang tidak dikehendaki. 
Hasil penelitian ini didukung oleh Kasman (2010) yang menyatakan bahwa wanita dengan tingkat pendidikan menengah keatas atau lebih tinggi lebih banyak mengalami kehamilan tidak diinginkan dibandingkan wanita yang berpendidikan rendah. Hasilnya menunjukkan wanita dengan pendidikan tersier memiliki rata-rata tiga kali lebih berisiko mengalami kehamilan tidak diinginkan dibandingkan mereka yang tidak berpendidikan. Oleh karena itu, secara keseluruhan pendidikan wanita yang makin tinggi meningkatkan kemungkinan mengalami kehamilan tidak diinginkan. Bila dilihat hubungan antara pendidikan dan pekerjaan terlihat bahwa wanita yang berpendidikan menengah memiliki kesempatan bekerja yang lebih besar dibandingkan mereka yang berpendidikan rendah, sehingga pada ibu yang berpendidikan menengah, kemungkinan waktu yang tersita untuk bekerja atau untuk melanjutkan pendidikannya ke jenjang yang lebih tinggi akan mengakibatkan tidak ingin menambah anak lagi.

Hal ini berbanding terbalik dengan penelitian Eva Muzdalifah (2008) yang menyatakan tidak terdapat hubungan yang signifikan antara tingkat pendidikan dengan kehamilan tidak diinginkan. Meskipun tidak terdapat hubungan yang signifikan, namun pada hasil penelitian terlihat bahwa ibu yang berpendidikan rendah memiliki proporsi yang lebih besar mengalami kehamilan tidak diinginkan dibandingkan ibu yang berpendidikan tinggi atau dapat dikatakan semakin rendah tingkat pendidikan responden, maka semakin meningkat pula angka kejadian kehamilan tidak diinginkan. Ibu yang berpendidikan tinggi akan lebih memahami tentang bagaimana mencegah kehamilan dengan cara memanfaatkan sarana pelayanan kesehatan yang telah disediakan, diantaranya mengikuti program keluarga berencana. Wanita yang berpendidikan lebih sedikit yang dilaporkan mengalami kehamilan tidak diinginkan dibandingkan dengan wanita yang tidak berpendidikan.

\section{Hubungan Paritas dengan Kejadian Kehamilan tidak Diinginkan pada Akseptor}

\section{Keluarga Berencana di Klinik PKBI As Sakinah Pemalang}

Berdasarkan hasil penelitian menunjukan bahwa ada hubungan paritas dengan kejadian kehamilan tidak diinginkan pada akseptor keluarga berencana di Klinik PKBI As Sakinah Pemalang dengan nilai $p 0,009<\alpha=0,05$.

Paritas adalah jumlah anak yang pernah dialami wanita (Manuaba, 2008). Banyaknya jumlah anak yang dilahirkan seseorang perempuan selama hidupnya sangat mempengaruhi kesehatannya. Pada kelahiran pertama, terdapat bahaya komplikasi yang agak tinggi bila dibandingkan pada kelahiran kedua atau ketiga. Kelahiran kedua atau ketiga umumnya lebih aman, namun pada kelahiran keempat dan 
selanjutnya, angka kematian bayi dan ibu semakin tinggi. Hal ini sesuai pernyataan WHO (2006) yang mengatakan bahwa seorang ibu yang memiliki anak lebih dari 3 dapat meningkatkan risiko terhdap kesehatan pada saat kehamilan dan melahirkan. Risiko kematian anak meningkat kurang lebih 50\% jika jarak antara 2 kelahiran kurang dari 2 tahun.

Hal ini sejalan dengan penelitian Shaheen (2007) yang mengatakan wanita yang memiliki anak lebih dari tiga orang akan meningkatkan kejadian kehamilan tidak diinginkan. Jumlah anak masih menjadi masalah di Indonesia, hal ini dikarenakan jumlah anak yang diinginkan setiap keluarga berbeda-beda. Bagi masyarakat berpenghasilan rendah dan tinggal didaerah pedesaan anak mempunyai nilai tinggi bagi keluarga. Anak dapat menjadi sumber kebahagiaan dan dapat membantu ekonomi keluarga, sedangkan pada kelompok berpenghasilan tinggi dan tinggal di perkotaan selain anak menjadi sumber kebahagiaan juga bersifat ekonomis. Pada kelompok ini orangtua akan mengkhawatirkan biaya yang dikeluarkan untuk makanan, kesehatan, pakaian, dan lainya cukup besar. Hal ini mengakibatkan jumlah anak sangat mempengaruhi keinginan seorang wanita untuk hamil.

\section{Kesimpulan}

Berdasarkan hasil penelitian dapat disimpulkan bahwa Ada hubungan antara pendidikan dengan kejadian kehamilan tidak diinginkan pada akseptor keluarga berencana di Klinik PKBI As Sakinah Pemalang. Ada hubungan antara paritas dengan kejadian kehamilan tidak diinginkan pada akseptor keluarga berencana di Klinik PKBI As Sakinah Pemalang.

\section{Saran}

Meningkatkan informasi bagi masyarakat agar dapat memotivasi ibu yang mengalami kejadian kehamilan tidak diinginkan supaya mempertahankan kehamilannya dan memberikan informasi bagi ibu dalam melindungi diri dari kehamilan agar benar-benar aman tidak mengalami kegagalan lagi. 


\section{Daftar Referensi}

Anonim. 2010. Aborsi dalam kesehatan reproduksi. http://www.who.int/entity/ kesehatanreproduksi/topik/aborsi_2010/artikel_aborsi_2010.pdf. Akses tanggal 4 Januari 2015 Pukul 05.00 WIB

- 2011. Laju pertumbuhan penduduk di Indonesia. http://princessglad.blogspot.com/2011/10/dampak-pertumbuhan-penduduk-diindonesia.html. Akses tanggal 3 Januari 2015 Pukul 19.00 WIB

Antari, Benta. 2013. Kehamilan tidak diinginkan. http://bebenta.blogspot.com/miscellaneous:kehamilan-tidak-diinginkan.html. Akses tanggal 3 Januari 2015 Pukul 16.00 WIB

Arikunto, Suharsimi. 2010. Prosedur Penelitian suatu Pendekatan Praktik. Jakarta : PT Rineka Cipta

Handayani, Sri. 2010. Buku Ajar Pelayanan Keluarga Berencana. Yogyakarta : Pustaka Rihama

Hartanto, Hanafi. 2009. Keluarga Berencana dan Kontrasepsi. Jakarta : Pustaka Sinar Harapan

Kadir, Ruslan. 2014. Angka Kematian Ibu. m.kompasiana.com//catatan-menjelang2014:angka-kematian-ibu-meningkat. Akses tanggal 3 Januari 2015 Pukul 20.00 WIB

Kompas. 2012. Aborsi Tak Aman Tingkatkan Resiko Kematian Ibu. http://nasional.kompas.com. Akses tanggal 3 Januari Pukul 21.00 WIB

Manuaba. 2008. Ilmu Kebidanan, Kandungan dan KB. Jakarta : EGC

Maulana, H.D. 2009. Promosi Kesehatan. Jakarta : EGC

Mochtar, Rustam. 2011. Sinopsis Obstetri : Obstetri Fisiologi, Obstetri Patologi Edisi 3. Jakarta : EGC

2012. Metodologi Penelitian Kesehatan Edisi Revisi. Jakarta : PT. Rineka Cipta

Praptohardjo, Untung. 2007. Fenomena Aborsi dan Implikasinya. Semarang : PKBI Daerah Jawa Tengah

Saefuddin, Azwar. 2009. Metode Penelitian. Yogyakarta : Pustaka Pelajar

Saifudin, A.B., Rachimhadhi, T., \& Wiknjosastro, G.H. 2008. Ilmu Kebidanan Sarwono Prawirohardjo edisi keempat. Jakarta : PT Bina Pustaka Sarwono Prawirohardjo

Yuhedi, Lucky Taufik. 2013. Kependudukan dan Pelayanan KB. Jakarta : EGC 